\title{
Multivariate analysis of lactose content in milk of Holstein and Jersey cows ${ }^{1}$
}

\section{Análise multivariada do teor de lactose do leite de vacas Holandês e Jersey}

\author{
Dileta Regina Moro Alessio ${ }^{2 *}$; André Thaler Neto ${ }^{3}$; João Pedro Velho ${ }^{4}$; \\ Ildemar Brayer Pereiras; David José Miquelluti ${ }^{6}$; Deise Aline Knob²; \\ Claudineli Gasparini da Silva ${ }^{2}$
}

\begin{abstract}
This study evaluated the factors influencing the variation in the lactose content of milk in Holstein and Jersey herds in Santa Catarina, southern Brazil, using multivariate analysis. Data from 73 dairy herds in the Dairy Herds Improvement Program of the State of Santa Catarina were provided by the Santa Catarina Association of Cattle Breeders (ACCB). A total of 46,242 monthly records of Holstein and Jersey (59 and $41 \%$ of the total records, respectively) cows from 2009 to 2012 were analyzed using multiple correspondence, factor, and cluster analyses. Lactose content was observed to correlate with somatic cell count and parity, whereas the evaluated breeds, as well as the production and concentrations of fat and protein in the milk, were not associated with the lactose content. The cows were categorized into three groups, the first consisting of cows of both breeds with low lactose content (4.19), high somatic cell score (5.82), and higher parity (2.50), contrasting with two other groups each with mean values characteristic for Holstein and Jersey breeds, respectively. Analysis of cows without subclinical mastitis $(<200,000$ somatic cells ml-1) revealed that the relationship of parity with lactose level was independent of the effect of somatic cells. Lactose contents less than $4.4 \%$ were observed in autumn. Overall, the present study suggests that the lactose content of milk is influenced by somatic cell count and parity and that it varies seasonally; however, it is not related to breed, milk yield, milk fat content, or milk protein level.
\end{abstract}

Key words: Analysis of correspondence. Cluster analysis. Factorial. Milk composition. Somatic cell count.

\section{Resumo}

Objetivou-se avaliar os fatores que influenciam a variação de lactose do leite bovino em rebanhos sobre controle leiteiro, através do emprego de análise multivariada. Os dados de controle leiteiro de 73

${ }_{1}^{1}$ Parte da dissertação de mestrado da primeira autora

2 Discentes do Curso de Doutorado do Programa de Pós-Graduação em Ciência Animal, Universidade do Estado de Santa Catarina, UDESC, Lages, SC, Brasil. E-mail: alessiodrm@gmail.com; deisealinek@hotmail.com; neligasparini@hotmail.com

3 Prof. Associado, Departamento de Produção Animal e Alimentos, Faculdade de Medicina Veterinária, Centro de Ciências Agroveterinárias, UDESC, Lages, SC, Brasil. E-mail: andre.thaler@udesc.br

${ }^{4}$ Prof. Adjunto, Departamento de Zootecnia e Ciências Biológicas, Campus Palmeira das Missões, Universidade Federal de Santa Maria, UFSM, Palmeira das Missões, RS, Brasil. E-mail: velhojp@ufsm.br

${ }_{5}^{5}$ Médico Veterinário, Associação Catarinense de Criadores de Bovinos, ACCB, Concórdia, SC, Brasil. E-mail: accbconcordia@ hotmail.com

${ }^{6}$ Prof. Titular Departamento de Solos e Recursos Naturais, Faculdade de Agronomia, Centro de Ciências Agroveterinárias, UDESC, Lages, SC, Brasil. E-mail: david.miquelluti@udesc.br

* Author for corresondence 
rebanhos do estado de Santa Catarina foram disponibilizados pela Associação Catarinense de Criadores de Bovinos (ACCB), totalizando 46.242 controles mensais de vacas das raças Holandês $(58,5 \%)$ e Jersey $(41,5 \%)$ no período de 2009 a 2012. Os dados de foram avaliados através de análise multivariada, utilizando análise de correspondência múltipla, fatorial e análise de agrupamento. $\mathrm{O}$ teor de lactose apresentou relação com a contagem de células somáticas e ordem de parto, enquanto raça, produção de leite, teor de gordura e proteína não apresentaram relação com teor de lactose. A análise de agrupamento revelou um grupo formado por vacas de ambas as raças com baixo teor de lactose $(4,19 \%)$, contagem de células somáticas alta $(5,82)$, e paridade mais elevada $(2,50)$, contrastando com outros dois grupos, cada um com valores médios característicos para as raças Holandês e Jersey, respectivamente. A análise de vacas sem mastite subclínica $\left(<200.000\right.$ células somáticas $\left.\mathrm{mL}^{-1}\right)$ demonstra que a relação de paridade com o nível de lactose é independente do efeito da contagem de células somáticas. Os valores inferiores a 4,4\% de lactose foram observados no outono. O teor de lactose do leite é influenciado pela contagem de células somáticas e paridade, com variação sazonal, mas não está relacionada a raça, produção de leite, teor de gordura e de proteína do leite.

Palavras-chave: Análise de agrupamento. Análise de correspondência. Composição do leite. Contagem de células somáticas. Fatorial.

\section{Introduction}

Lactose is the main carbohydrate in cows' milk, representing approximately $40 \%$ of the total solids and $50 \%$ of the nonfat solids. The mammary gland of cows absorbs 70 to $80 \%$ of the entire amount of glucose available. The energy derived by the mammary glands from glucose is essential for milk production, and factors that affect the availability of glucose directly influence the production and composition of milk, especially its lactose content (POLLOTT, 2004; LEMOSQUET et al., 2009).

Lactose content in milk has been reported to vary, values of 4.7 (FORSBÄCK et al., 2010), 4.5 (NORO et al., 2006; MIGLIOR et al., 2007), as well as values in between 4.39 and $4.29 \%$ (ZANELA et al., 2009), and $4.28 \%$ (GONZALEZ et al., 2009) have been reported previously. Low content of lactose affects the performance of dairy products, especially powdered milk, and also hinders the coagulation of milk for cheese production (LEITNER et al., 2011). This problem has concerned the dairy industry in Brazil, where the management conditions, feeding of dairy herds and health of the mammary glands are still quite heterogeneous. Few studies have, however, been reported in which the causes for low lactose content in milk under the above-mentioned conditions have been investigated.
The concentration of lactose has also been reported to be influenced by high milk somatic cell counts (SCC). Berglund et al. (2007) observed that an increase from 31,000 to 450,000 somatic cells $\mathrm{mL}^{-1}$ reduced the lactose content from 4.86 to 4.69 $\%$. This was due to a reduction in lactose secretion (LEITNER et al., 2007) and loss of lactose to the bloodstream (BEN CHEDLY et al., 2009) because of increased of permeability of the tight junction (MOUSSAOUI et al., 2004).

The concentration of lactose in milk is influenced by multiple factors. Therefore the use of multivariate techniques is convenient to examine the factors involved, since conventional analyses can capture the effect of only one or two factors (MACCIOTTA et al., 2012). Factor analysis allows the replacement of the number of original variables by a set of variables that have a relation to each other (factors), enabling a reduction in the number of parameters to be estimated without a significant reduction in the adjustment (MACCIOTTA et al, 2012; BIGNARDI et al., 2012). Multiple correspondence analysis is analogous to factor analysis, and its use is associated with exploratory research involving multidimensional categorical variables that interact to form a structure (LEBART et al., 2000; TEIXEIRA et al., 2012.). With the cluster analysis, the elements of a data set can be grouped 
into subgroups, considering that the similarity between the elements within the group is greater than the similarity between the groups (CAMPOS; CARVALHO, 2007). However, a huge amount of information requires appropriate statistical tools to draw inferences about the causes of variation and study the pattern of relationships, having on the factor analysis, a valuable option (MACCIOTTA et al., 2012), as well as multiple correspondence and grouping analysis.

Thus, multivariate techniques, multiple correspondence analysis, factor, and cluster analysis allow verification of the relationship between the factors responsible for the variation in lactose content. However, some studies have shown that the lactose content shows considerable variation in countries such as Brazil (GONZALEZ et al., 2009; ZANELA et al., 2009), where management systems, feeding practices, and herd health are quite varied. The objective was to evaluate the factors influencing lactose variation in the milk of cows enrolled in the Dairy Herd Improvement (DHI) program in Santa Catarina, southern Brazil using multivariate analysis.

\section{Material and Methods}

Data collected during the period from 2009 to 2012 from DHI evaluation of 73 dairy herds were provided by the Santa Catarina Association of Cattle Breeders (ACCB). The database consisted of the date of milking, breed, parity, days in milk (DIM), milk yield, fat content, protein, lactose content, and somatic cell count for individual animals. Most farms in the ACCB have mechanized milking and milk cooling tanks, and use pasture as the primary source of feed, which is supplemented with corn silage and concentrated feed.

Milk yield was measured monthly in each farm. Samples were collected after homogenization of milk in 40-mL bottles containing Bronopol, an antimicrobial compound. Each sample was composed of the morning and afternoon milking and was sent to the State Laboratory of Milk Quality located in Concordia, SC, Brazil. All the analyses were performed using automated equipment (Soma Count FC and Dairy Spec FT Bentley®). The somatic cell counts (SCC) analysis was performed using flow cytometry, according to the ISO 13366-2 method and the milk composition was determined by an infrared technique, according to ISO 9622 guidelines, both these methods are prescribed by the INMETRO IEC 17025:2002.

A total of 46,242 DHI records were used for the analyses; these records were for Holstein (59 $\%$ ) and Jersey (41\%) cows. The SCC data were transformed to somatic cell score (SCS) using the equation SCS $=\log _{2} \frac{\text { SCC }}{\mathbf{1 0 0}}+3$, according to Shook and Schutz (1994). Cows were grouped on the basis of their parity $(1,2, \geq 3)$ and breeds were coded as 1 for Holstein and 2 for Jersey. The seasons for which the data included were defined as summer (December, January, and February), autumn (March, April, and May), winter (June, July, and August), and spring (September, October, and November), the state of Santa Catarina is characterized by subtropical climate with defined seasons, of the CFA and $\mathrm{Cfb}$ types, as per the Köppen classification (PEEL et al., 2007).

Data were analyzed using multivariate analysis techniques (factor analysis, clustering, and multiple correspondence), using $\mathrm{SAS}^{\circledR}$ software (SAS INSTITUTE, 2002). To carry out the analysis, data were first standardized. DHI data from Holstein and Jersey cows were analyzed together as well as separately for both the breeds. Factor and cluster analyses were also conducted on a data set composed of DHI records from cows considered healthy with regard to subclinical mastitis (i.e., cows with $\mathrm{SCC}<$ 200,000 $\mathrm{mL}^{-1}$ ), according to Schukken et al. (2003), to evaluate the relationships between the variables used in the study, apart from the effect of SCC.

Factor analysis allows the evaluation of the relationship between the variables, aiming to reduce the original data set of variables into a smaller 
number of factors, grouping in each factor the most correlated variables. To check the suitability of the model, the statistics Kaiser-Meyer-Olkin (KMO) was used, which is considered an indicator that compares the magnitude of the correlation coefficients observed for partial correlation coefficients. The variables were selected to compose the factors by their commonality, which represents the proportion of the variance of the original variables that are explained by the common factor. The number of factors was defined by the eigenvalue, using all eigenvalues higher than one. Factor loadings $\geq 0.4$ were considered significant. Promax rotation was used, which is an oblique rotation that considers the relationship between the factors.

The cluster analysis was used as a complement of the factor analysis, which can improve the comprehension of these relations through the formation of groups with similarity within their selves and differences between the groups. It used the Ward hierarchical method, which is based on Euclidean distance; the standardized means of the groups were estimated and later transformed into the original averages for each group. The cluster analysis was complemented by discriminant analysis with the stepdisc method, to list the variables that differentiated the groups. The standardized average of the three groups formed were compared to identify the difference between the groups using multivariate analysis of variance (MANOVA) and the Tukey-Kramer test, at a significance level of $1 \%$.

A multiple correspondence analysis was used to analyze the relationship between the categorical variables (seasons) and the variables that represented the composition of milk. This analysis was performed with the original data and numerical variables were classified as low and high. Thresholds were adopted based on the average, prioritizing the homogeneity of the number of observations for each formed class, being considered: $3.6 \%$ for fat, $3.3 \%$ for protein, and $4.4 \%$ for lactose. The number of dimensions was determined by the average of the eigenvalues, considering all eigenvalues higher than the average. In the input matrix, lines corresponded to the seasons and the columns represented fat, protein, and lactose content in the milk, and each value for a variable, which represented the composition of milk could only assume a category (season), according to the statistical model:

$$
\mathrm{Yij}=\mathrm{Zij} /\left(\mathrm{Vr}_{\mathrm{i}} \times \mathrm{c}_{\mathrm{j}}\right)
$$

where $\mathrm{Yij}$ is the expected outcome for the dependent variable $\mathrm{Y}$ for the $\mathrm{i}^{\text {th }}$ observation in the $\mathrm{j}^{\text {th }}$ category;

$\mathrm{Zij}$ is the indicator matrix with $\mathrm{n}$ lines (season) and p columns (milk composition);

$r_{i}$ is the reference value for the $i^{\text {th }}$ observation on line;

$\mathrm{Cj}$ is the reference value for the $\mathrm{j}^{\text {th }}$ observation on column.

\section{Results}

The descriptive statistics (Table 1) of the DHI records showed that there was considerable variation in the production and composition of milk, and especially in the SCC. In the factor analysis on full data set, three factors were considered, which explained $69 \%$ of the total variation (Table 2). The model adopted by factor analysis was considered satisfactory for the set of variables used, according to the statistics KMO (0.7049). Communalities demonstrated the high relevance of each variable used in this analysis, as the values above 50 indicate that variables were essential for the analysis (Table $3)$. Factor 1 variables with higher factor loading were breed, yield, and composition of milk. The negative factor loading for milk production indicated that this factor had a negative relationship with fat, protein, and the genetic group, as Jersey cows (code 2) had lower milk production and higher fat and protein than Holsteins (code 1). The second factor consisted of SCS and parity, which were positively related with each other and had an inverse relationship to 
the lactose content. The third factor was represented by the negative relationship between DIM with parity and milk yield, which, in turn, had positive relationship with parity. Multiparous cows produce more milk, which is related to the beginning of lactation. The results show that breed, milk yield, fat, protein, and DIM are not related to the lactose content (Table 3).

Table 1. Descriptive statistics of data from dairy herd improvement assessments of Holstein and Jersey cows for 20092012; the herds were enrolled in the Santa Catarina Association of Cattle Breeders (ACCB), Santa Catarina, Brazil.

\begin{tabular}{lcccc}
\hline Variables & Minimum & Average & Maximum & SD $^{1}$ \\
\hline Milk yield $\left(\mathrm{kg} \mathrm{day}^{-1}\right)$ & 8.00 & 23.87 & 77.50 & 9.15 \\
Fat $(\%)$ & 2.00 & 3.70 & 7.99 & 0.92 \\
Protein $(\%)$ & 2.00 & 3.34 & 5.00 & 0.45 \\
Lactose (\%) & 3.60 & 4.47 & 5.30 & 0.26 \\
Days in milk & 8.00 & 169.88 & 400.00 & 100.21 \\
SCC $(\times 1000)^{2}$ & 1.00 & 557.52 & $9,999.00$ & $1,012.19$ \\
\hline
\end{tabular}

${ }^{1} \mathrm{SD}=$ standard deviation; ${ }^{2} \mathrm{SCC}=$ somatic cell count.

Table 2. Eigenvalue, percentage of variance explained, and cumulative variance of each eigenvalue considered in the factor analysis.

\begin{tabular}{lccc}
\hline Factor & Eigenvalue & Explained variance & Cumulative variance \\
\hline 1 & 2.85 & 35.6 & 35.6 \\
2 & 1.53 & 19,2 & 54.8 \\
3 & 1.12 & 14.0 & 68.9 \\
\hline
\end{tabular}

Table 3. Factor loadings and communalities of each variable of the complete data from dairy herd improvement tests of Holstein and Jersey cows.

\begin{tabular}{lcccc}
\hline \multirow{2}{*}{ Variables } & \multicolumn{3}{c}{ Factor loadings } & \multirow{2}{*}{ Communalities } \\
\cline { 2 - 4 } & Factor 1 & Factor 2 & Factor 3 & \\
\hline Breed & $\mathbf{0 . 8 8 7 6}$ & 0.0026 & -0.2597 & 78.80 \\
Milk Yield $\left(\mathrm{kg} \mathrm{day}^{-1}\right)$ & $\mathbf{- 0 . 6 5 5 2}$ & -0.0179 & -0.3492 & 62.03 \\
Fat (\%) & $\mathbf{0 . 8 4 8 7}$ & -0.0590 & -0.0427 & 69.87 \\
Protein (\%) & $\mathbf{0 . 7 9 1 0}$ & 0.0344 & 0.2272 & 74.27 \\
SCS $^{1}$ & -0.1333 & $\mathbf{0 . 7 3 8 2}$ & 0.1942 & 59.8 \\
Parity order & 0.0308 & $\mathbf{0 . 7 1 9 3}$ & -0.4521 & 63.85 \\
Lactose (\%) & -0.1020 & $\mathbf{- 0 . 7 4 9 8}$ & -0.1411 & 65.13 \\
Days in milk & 0.0203 & 0.0846 & $\mathbf{0 . 8 6 3 3}$ & 77.83 \\
\hline
\end{tabular}

${ }^{1} \mathrm{SCS}=$ somatic cell score.

The distribution of the first two factors allows us to visualize the relationships between the variables (Figure 1). In the first factor, breed, fat, and protein levels had a positive relationships with each other and a negative relationship to milk production, whereas in the second factor there was a positive relationship between SCS and parity, with both being inversely related to the lactose content. 
In the discriminant analysis, performed through the stepdisc method, all the variables were included in the final model $(\mathrm{P}<0.0001)$. Cluster analysis suggested that there were three distinct groups when all the factors of breed, milk yield and composition, health of mammary gland, and age of the animals were considered (Table 4). Group 1 consisted mainly of Jersey cows (code 2) with lower milk production and higher content of solids. Group 2 consisted mainly of Holstein cows (code 1) with higher milk yield and lower fat and protein levels. Group 3 consisted of cows of both the breeds, with high SCC (5.82) and low lactose (4.19\%), parity greater than 2, and some increase in DIM.

Figure 1. Distribution of first two factors affecting lactose content based on complete data from dairy herd improvement assessments of Holstein and Jersey cows.

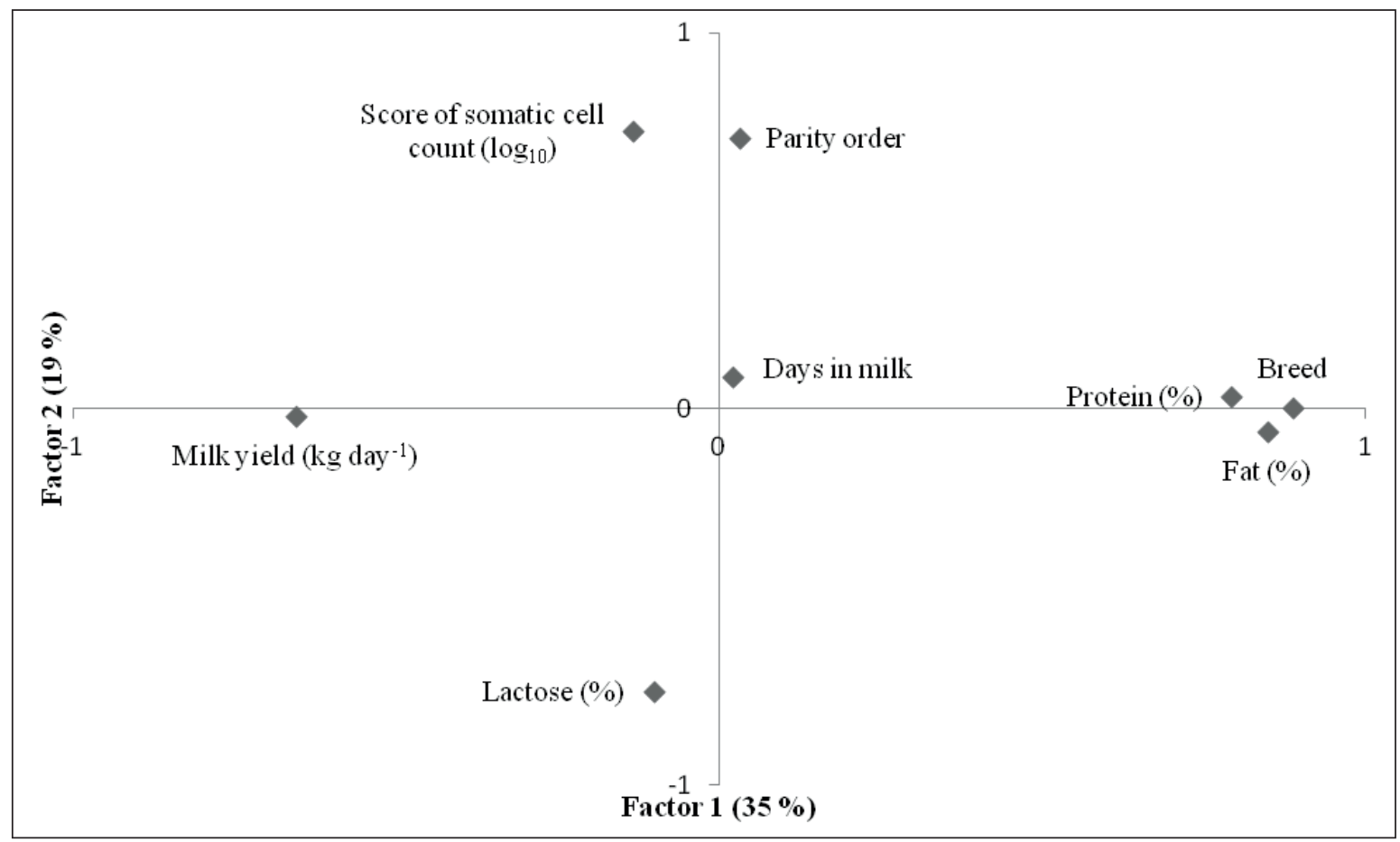

Table 4. Groupings of the complete data from dairy herd improvement programs of Holstein and Jersey cows.

\begin{tabular}{lccc}
\hline Variables & Group 1 & Group 2 & Group 3 \\
\hline Breed $^{1}$ & $1.95 \mathrm{c}$ & $1.02 \mathrm{a}$ & $1.57 \mathrm{~b}$ \\
Milk Yield $\left(\mathrm{kg} \mathrm{day}^{-1}\right)$ & $18.92 \mathrm{~b}$ & $29.61 \mathrm{a}$ & $18.22 \mathrm{c}$ \\
Fat $(\%)$ & $4.40 \mathrm{a}$ & $3.14 \mathrm{c}$ & $3.98 \mathrm{~b}$ \\
Protein (\%) & $3.62 \mathrm{a}$ & $3.03 \mathrm{c}$ & $3.60 \mathrm{~b}$ \\
Days in milk & $146.82 \mathrm{c}$ & $152.24 \mathrm{~b}$ & $231.85 \mathrm{a}$ \\
Lactose (\%) & $4.54 \mathrm{~b}$ & $4.57 \mathrm{a}$ & $4.19 \mathrm{c}$ \\
SCS $^{2}$ & $3.09 \mathrm{c}$ & $3.61 \mathrm{~b}$ & $5.82 \mathrm{a}$ \\
Parity $^{3}$ & $1.80 \mathrm{c}$ & $1.86 \mathrm{~b}$ & $2.50 \mathrm{a}$ \\
\hline Number of observations $^{2}$ & 12.981 & 22.138 & 11.123 \\
\hline
\end{tabular}

${ }^{1} 1=$ Holstein and $2=$ Jersey; ${ }^{2} \mathrm{SCS}=$ somatic cell score; ${ }^{3}$ Parity order being $1=$ First calving, $2=$ second calving, and $3=$ three or more calvings; different letters represent significant differences in lines by Tukey-Kramer test with $\mathrm{P}<0.0001$ for all the variables. 
A separate factorial analysis by breed (Tables 5) revealed that only two factors explained 53 and $55 \%$ of the total variation, for Holstein and Jersey, respectively. The factors were similar in both the breeds, with the first factor being milk yield, which had a negative relationship to fat and protein content in milk and to DIM. The second factor was the SCS value and the parity level, which were negatively related to the lactose level.
In the factor analysis of cows without subclinical mastitis $\left(<200,000\right.$ somatic cells $\left.\mathrm{mL}^{-1}\right), 58 \%$ of the total variation was explained by the first two factors (Figure 2). The logic of the first factor remained similar to the factor analysis of the whole data set (Table 3) and was separated by breed (Table 5). The second factor demonstrates that parity had an inverse relationship with the lactose level, independent of the effect of somatic cell.

Figure 2. Distribution factor loadings of data from the dairy herd improvement programs for cows considered healthy with SCC $<200,000$ somatic cells $/ \mathrm{mL}^{-1}$. Parity order being $1=$ first parity, $2=$ second parity, and $3=$ three or more parities.

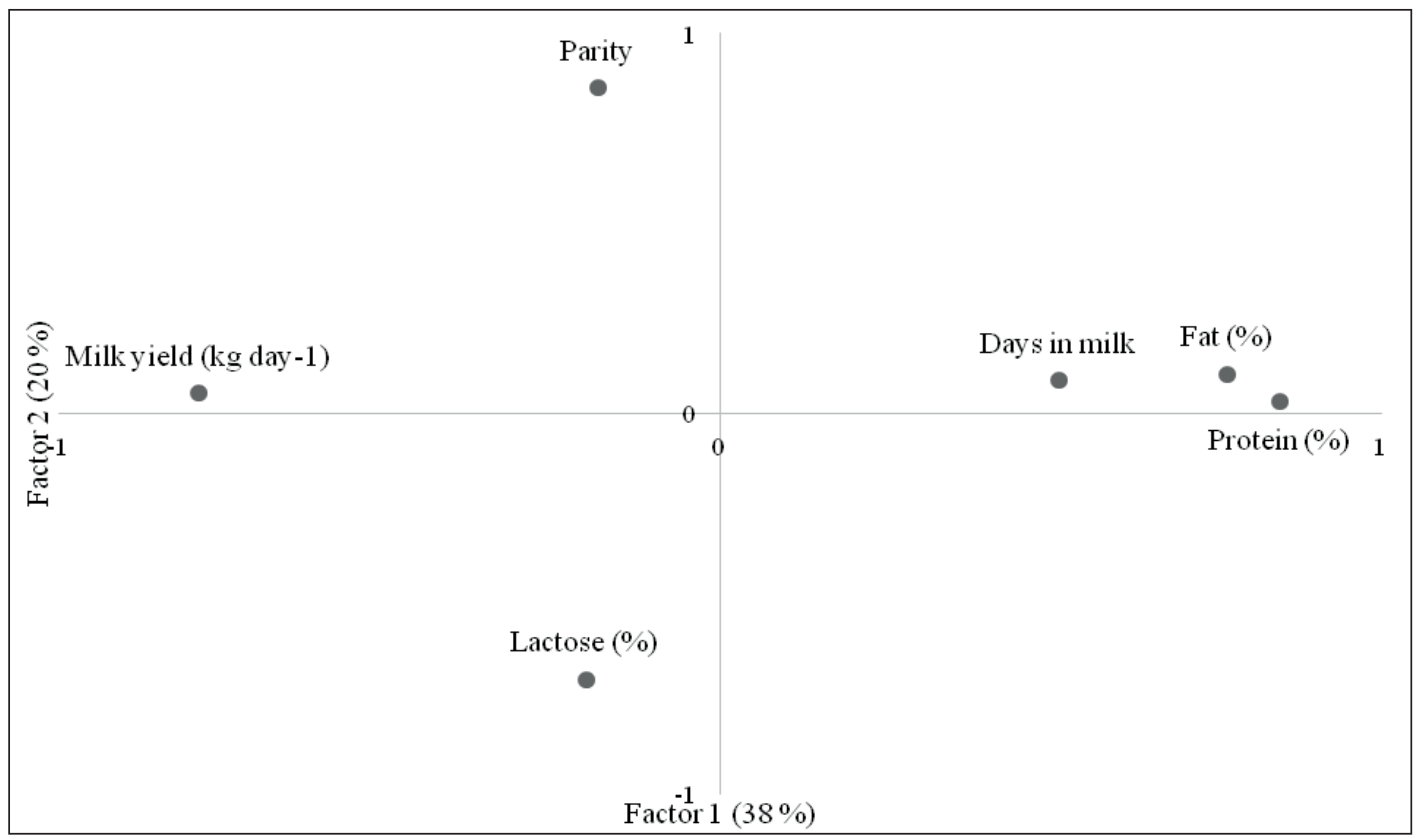

Table 5. Factor loadings and percentage of variance for each variable of individual data from dairy herd improvement tests of Holstein and Jersey cows, analyzed separately.

\begin{tabular}{|c|c|c|c|c|}
\hline \multirow{3}{*}{ Variables } & \multicolumn{4}{|c|}{ Factor loadings } \\
\hline & \multicolumn{2}{|c|}{ Holstein } & \multicolumn{2}{|c|}{ Jersey } \\
\hline & Factor 1 & Factor 2 & Factor 1 & Factor 2 \\
\hline Protein $(\%)$ & 0.7965 & -0.0414 & 0.7711 & 0.0751 \\
\hline Fat $(\%)$ & 0.6154 & -0.1923 & 0.6600 & -0.1349 \\
\hline Milk yield $\left(\mathrm{kg} \mathrm{dia}^{-1}\right)$ & -0.7014 & -0.0881 & -0.6992 & -0.0888 \\
\hline Days in milk & 0.6686 & 0.1304 & 0.7252 & 0.0880 \\
\hline Lactose (\%) & -0.0848 & -0.7812 & -0.2198 & -0.7632 \\
\hline $\operatorname{SCS}^{1}$ & 0.1320 & 0.7146 & -0.0075 & 0.7770 \\
\hline Parity & -0.2534 & 0.6715 & -0.2478 & 0.6736 \\
\hline Variance explained (\%) & 31 & 21 & 33 & 22 \\
\hline
\end{tabular}

${ }^{1} \mathrm{SCS}=$ somatic cell score. 
In multiple correspondence analyses between be shown by the fact that low lactose levels were milk composition and the seasons, three related to autumn and high levels were correlated dimensions were considered, which explained to spring, whereas the concentrations of fat and $60 \%$ of the inertia (Table 6). The relationship protein were less correlated to the season (Figure between the dimensions one and two could only 3).

Table 6. Eigenvalue, percentage of explained inertia, and cumulative inertia of each eigenvalue considered in factor analysis.

\begin{tabular}{cccc}
\hline Dimension & Eigenvalue & Explained inertia & Cumulative inertia \\
\hline 1 & 0.629 & 26.4 & 26.4 \\
2 & 0.505 & 17.0 & 43.4 \\
3 & 0.500 & 16.6 & 60.1 \\
\hline
\end{tabular}

Figure 3. Effect of season and other factors on lactose levels in dairy herds of the Santa Catarina Association of Cattle Breeders (ACCB), Santa Catarina, Brazil, during 2009-2012.

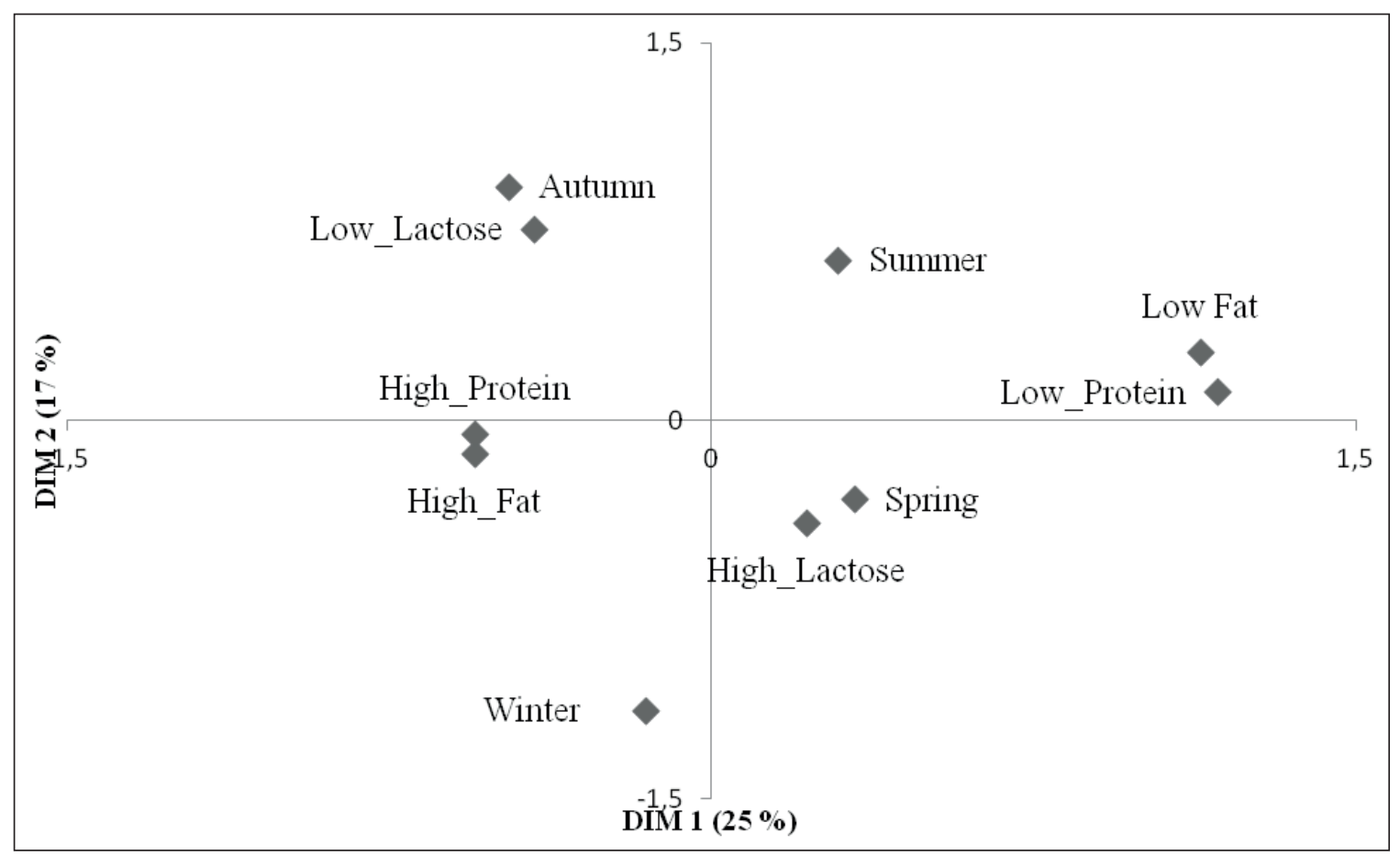

\section{Discussion}

Although the average lactose content in milk from cows used in the study was adequate $(4.47$ $\%$, there was a considerable variation (3.60$5.30 \%$, Table 1), which may have been related to the nutritional status and mammary gland health of the included herds. According to Jenkins and McGuire (2006), in developed dairying regions, lactose levels are practically constant because there are fewer problems of mammary glands, somatic cell counts (SCC) are lower, and cows receive appropriate nutrition. The mean observed value of 
$4.47 \%$ obtained in this study is close to the values considered appropriate by Miglior et al. (2007), Noro et al. (2006), and Forsbäck et al. (2010).

Although standard deviation in the lactose content $(0.26 \%)$ was smaller than that of other components of milk, an important share of the evaluated milk samples had a lactose content that would not meet the requirements of the dairy industry, affecting both the yield and the quality of dairy products. Low values for lactose content have been reported in previous studies (GONZALEZ et al., 2009; ZANELA et al., 2009). Intense variability was observed in the levels of proteins and fats, but the factors that influence these have been corrected by milk prices based on fat and protein contents.

Substantial reductions in the lactose levels were correlated with the increase in SCS, as observed in the factor analysis, in which the lactose content had contrary relationship with SCS (-0.7498, 0.7382). This relationship remained the same in separate factor analyses by breed $(-0.7812,0.7146$ for Holstein) and (-0.7632, 0.7770 for Jersey). This is evident in Figure 1 by the formation of angle next to 180 degrees between lactose content and SCS and Tables 3 and 5. This relationship was confirmed by the cluster analysis (Table 4 ), where a reduction in lactose content (4.19\%) happened due to an increase in SCS (5.82). Similarly, Berglund et al. (2007) observed that an increase from 31,000 to 450,000 somatic cells $\mathrm{mL}^{-1}$ reduced the lactose levels from 4.86 to $4.69 \%$. Phenotypic and genetic correlations of -0.774 and -0.227 between the lactose content and SCS were estimated by Lindmark-Månsson et al. (2006) and Miglior et al. (2007), respectively.

The increase in SCS, which is an indicator of clinical and subclinical mastitis, decreases the lactose levels in milk, due to changes in the homeostasis of mammary glands (PESSOA et al., 2012), increasing the blood concentration of lactose (BEN CHEDLY et al., 2009). The increased permeability of mammary epithelium is associated with mastitis (MOUSSAOUI et al., 2004). Endotoxins of microorganisms and inflammatory mediators causing increased permeability of the tight junctions between the apical borders of alveolar epithelial cells (CAPUCO et al., 2003; SCHNEEBERGER; LYNCH, 1992) have been reported to increase the blood concentration of lactose, which is an indicator of the integrity of the mammary epithelium (BEN CHEDLY et al., 2009; STELWAGEN et al., 1994). Blood lactose is increased in cases of subclinical mastitis and, in a more pronounced way, in clinical mastitis (LEITNER et al., 2004). However, in subclinical mastitis the integrity of tight junctions is partly maintained. Leitner et al. (2007) argued that the lower concentration of lactose in cows with intramammary infection was also related to the reduction in the secretion of lactose by further conversion of plasminogen to plasmin. This conversion causes the release of $\beta$-casein 1-28, which has the ability to block potassium channels, thereby, reducing the release of lactose into the lumen of the mammary alveoli (LEITNER et al., 2004; MOUSSAOUI et al., 2004; SILANIKOVE et al., 2009, 2013). Among the possible causes of this influence of mastitis on lactose content could be the utilization of lactose by pathogens, it being an important nutritional substrate (BLUM et al., 2008).

Lactose levels were also correlated with parity (Tables 3, 5 and Figure 1), as indicated by the contrary factor loads of the whole dataset $(-0.7382$, 0.7193 ) and by individual analysis by breed Holstein $(-0.7812,0.6715)$ and Jersey $(-0.7632$, $0.6736)$, as well as based on the cluster analysis (Table 4), which revealed a reduction in lactose (4.19\%) in older cows (2.50). While parity had lesser effect on lactose concentration than SCS, the effects of these two factors on lactose levels were independent. In factor analysis of cows without subclinical mastitis (SCC $<200,000 \mathrm{~mL}^{-1}$ ), a negative correlation of lactose levels with parity was observed, demonstrated by the angle next of 180 degrees formed between lactose and SCC (Figure 2). The reduction in the lactose content with increasing parity, along with a concomitant increase 
in SCC was also reported by Miglior et al. (2007) in Canada, with average values of $4.71 \%$ obtained for young cows (1st and 2nd calvings) and $4.53 \%$ for adult cows. The effect of parity on the lactose level independent of SCC determined in this study can be explained by the availability of endogenous glucose, because primiparous cows do not express all their productive potential, requiring lower percentage of body glucose compared to that by multiparous cows with high production, in which the available glucose is the substrate for the synthesis of lactose (RIGOUT et al., 2002; QIAO et al., 2005).

The lactose levels in milk were not related to breed, DIM, milk yield, and fat and protein levels, represented by the lower factor loadings and the formation of an angle close to 90 degrees (Tables 3 to 5, Figure 1 and 2). However, these variables were compared with each other, and fat and protein levels showed positive relationship with DIM (angle close to zero). These variables had an opposing relationship to milk yield (angle close to 180 degrees). These relationships are well defined and discussed in the literature (MIGLIOR et al., 2007, FORSBÄCK et al., 2010). Moreover, Holstein cows tend to have higher milk yield $\left(29.61 \mathrm{~kg} \mathrm{dia}^{-1}\right.$ in group 2, predominantly containing Holstein cows) whereas Jerseys tend to have higher concentration of solids (4.4 and $3.62 \%$ for fat and protein levels, respectively, in group 1, predominantly containing Jersey cows (Table 4). The differences between Holsteins and Jerseys in the production and composition of milk have been widely reported in the literature, in works such as those of Freyer et al. (2008), Smith et al. (2013) and Miglior et al. (2007) and such results corroborate with those obtained in the present work.

Milk samples collected in the fall had lower lactose levels than those collected in the spring (Figure 3), indicated by the angle close to zero for low lactose levels in the autumn. Heck et al. (2009) related this effect to the seasonal variation in the quality and quantity of food. The low level of lactose in the fall likely stemmed from the varying climatic conditions in southern Brazil, and the fact that some dairy farmers lack sufficient quantity and quality of roughage in the fall. Spring, on the other hand, is characterized by an abundance of grasses, especially Lolium multiflorum and Avena spp. (NORO et al., 2006). These differences between the seasons affect the food intake, metabolism of nutrients, and therefore, the availability of glucose, which is the substrate for the synthesis of lactose (RIGOUT et al., 2002; QIAO et al., 2005), with consequently impacts the milk yield and composition.

Quality-based payment systems have prioritized indicators such as high fat and protein levels, and low SCC and total bacterial counts. In this evaluation of payment based on milk quality, lactose content is not considered, because it is almost constant. However, considering the importance of lactose content in the milk to the dairy products, mainly powdered milk, in countries such as Brazil, where we observed considerable variation in the lactose levels, the lactose content could be used as an indicator for quality-based payment. This could not only improve the quality of milk but also the yield of the finished product. Because lactose, which aids in the osmotic regulation of milk under normal circumstances, is very stable under these conditions, its variation may be helpful in detecting changes in the health of mammary glands (LINDMARK-MÅNSSON et al., 2006; BERGLUND et al., 2007) as well as in nutrition and energy metabolism. Monitoring the lactose levels may help in the quality control and management of farms, helping in the identification of low quality milk (LEITNER et al., 2011) and energy inefficiencies (RIGOUT et al., 2002; QIAO et al., 2005).

\section{Conclusion}

The lactose content in milk is influenced by somatic cell count, parity, and season, but is not related to breed, days in milk, milk yield, as well as to the fat and protein levels in milk. The analytical techniques used in this study (factor 
analysis, clustering, and multiple correspondence) are appropriate for studying traits, such as lactose concentration in raw milk, that are influenced by multiple factors.

\section{Acknowledgments}

We would like to thank the Santa Catarina Association of Cattle Breeders (ACCB) for providing milk recording data of the Dairy Herds Improvements Programs and the research funding agencies Coordenação de Aperfeiçoamento de Pessoal de Nível Superior (CAPES) for the scholarships granted to the post-graduate students participating in the study.

\section{References}

BEN CHEDLY, H.; LACASSE, P.; MARNET, P. G.; WIART-LETORT, S.; FINOT, L.; BOUTINAUD, M. Cell junction disruption after $36 \mathrm{~h}$ milk accumulation was associated with changes in mammary secretory tissue activity and dynamics in lactating dairy goats. Journal of Physiology and Pharmacology, Kraków, v. 60, n. 3, p. 105-111, 2009.

BERGLUND, I.; PETTERSSON, G.; OSTENSSON, K.; SVENNERSTEN-SJAUNJA, K. Quarter milking for improved detection of increased SCC. Reproduction in Domestic Animals, Malden, v. 42, n. 4, p. 427-432, 2007.

BIGNARDI, A. B.; El FARO, L.; ROSA, G. J.; CARDOSO, V. L.; MACHADO, P. F.; ALBUQUERQUE, L. G. Principal components and factor analytic models for test-day milk yield in Brazilian Holstein cattle. Journal of Dairy Science, Champaign, v. 95, n. 4, p. 2157-2164, 2012.

BLUM, S.; HELLER. E. D.; KRIFUCKS, O.; SELA, S.; HAMMER-MUNTZ, O.; LEITNER, G. Identification of a bovine mastitis Escherichia coli subset. Veterinary Microbiology, Amsterdam, v. 132, n. 1-2, p. 135-148, 2008.

CAMPOS, K. C.; CARVALHO, H. R. Análise estatística multivariada: uma aplicação na atividade agrícola irrigada do município de Guaiúba-CE. Revista de Economia da UEG, Anápolis, v. 3, n. 1, p. 107-124, 2007.

CAPUCO, A. V.; ELLIS, S. E.; HALE, S. A.; LONG, E.; ERDMAN, R. A.; ZHAO, X.; PAAPE, M. J. Lactation persistency: Insights from mammary cell proliferation studies. Journal of Animal Science, Champaign, v. 81, n. 3, p. 18-31, 2003.
FORSBÄCK, L.; LINDMARK-MÅNSSON, H.; ANDREN, A.; ÅKERSTEDT, M.; ANDRÉE, L.; SVENNERSTEN-SJUANJA, K. Day-to-day variation in milk yield and milk composition at the udder-quarter level. Journal of Dairy Science, Champaign, v. 93, n. 8, p. $3569-3577,2010$.

FREYER, G.; KONIG, S.; FISCHER, B.; BERGFELD, U.; CASSELL, B. G. Invited review: crossbreeding in dairy cattle from a German perspective of the past and today. Journal of Dairy Science, Champaign, v. 91, n. 10, p. 3725-3743, 2008.

GONZALEZ, H. L.; HAYGERT-VELHO, I. M. P.; SILVA, M. A. da; MEDEIROS, R. B.; PAIM, N. R.; NÖRNBERG, J. L. Milk quality of Jersey cows kept on winter pasture supplemented or not with concentrate. Revista Brasileira de Zootecnia, Viçosa, MG, v. 38, n. 10, p. 1983-1988, 2009.

HECK, J. M. L.; VAN VALENBERG, H. J. F.; DIJKSTRA, J.; VAN HOOIJDONK, A. C. M. Seasonal variation in the Dutch bovine raw milk composition. Journal of Dairy Science, Champaign, v. 92, n. 10, p. 4745-4755, 2009.

JENKINS, T. C.; McGUIRE, M. A. Major advances in nutrition: impact on milk composition. Journal of Dairy Science, Champaign, v. 89, n. 4, p. 1302-1310, 2006.

LEBART, L.; MORINEAU, A.; PIRON, M. Statistique exploratoire multidimensionnelle. $3^{\text {th }}$ ed. Paris: Dunod, 2000. $456 \mathrm{p}$.

LEITNER, G.; CHAFFER, M.; SHAMAY, A.; SHAPIRO, F.; MERIN, U.; EZRA, E.; SARAN, A.; SILANIKOVE, N. Changes in milk composition as affected by subclinical mastitis in sheep. Journal of Dairy Science, Champaign, v. 87, n. 1, p. 46-52, 2004.

LEITNER, G.; MERIN, U.; LAVI, Y.; EGBER, A.; SILANIKOVE, N. Aetiology of intramammary infection and its effect on milk composition in goat flocks. Journal of Dairy Research, London, v. 74, n. 2, p. 186-193, 2007.

LEITNER, G.; MERIN, U.; SILANIKOVE, N. Effects of glandular bacterial infection and stage of lactation on milk clotting parameters: comparison among cows goats and sheep. International Dairy Journal, Barking, v. 21, n. 4, p. 279-285, 2011.

LEMOSQUET, S.; DELAMAIRE, E.; LAPIERRE, H.; BLUM, J. W.; PEYRAUD, J. L. Effects of glucose propionic acid and nonessential amino acids on glucose metabolism and milk yield in Holstein dairy cows. Journal of Dairy Science, Champaign, v. 92, n. 7, p. 3244-3257, 2009. 
LINDMARK-MÅNSSON， H.; BRANNING， C.; ALDEN, G.; PAULSSON, M. Relationship between somatic cell count individual leukocyte populations and milk components in bovine udder quarter milk. International Dairy Journal, Barking, v. 16, n. 7, p. 717727, 2006.

MACCIOTTA, N. P. P.; CECCHINATO, A.; MELE, M.; BITTANTE, G. Use of multivariate factor analysis to define new indicator variables for milk composition and coagulation properties in Brown Swiss cows. Journal of Dairy Science, Champaign, v. 95, n. 12, p. 7346-7354, 2012.

MIGLIOR, F.; SEWALEM, A.; JAMROZIK, J.; BOHMANOVA, J.; LEFEBVRE, D. M.; MOORE, R. $\mathrm{K}$. Genetic analysis of milk urea nitrogen and lactose and their relationships with other production traits in Canadian Holstein cattle. Journal of Dairy Science, Champaign, v. 90, n. 5, p. 2468-2479, 2007.

MOUSSAOUI, F.; VANGROENWEGHE, F.; HADDADI, K.; LE ROUX, Y.; LAURENT, F.; DUCHATEAU, L.; BURVENICH, C. Proteolysis in milk during experimental Escherichia coli mastitis. Journal of Dairy Science, Champaign, v. 87, n. 9, p. 2923-2931, 2004.

NORO, G.; GONZÁLEZ, F. H. D.; CAMPOS, R.; DÜRR, J. W. Fatores ambientais que afetam a produção e a composição do leite em rebanhos assistidos por cooperativas no Rio Grande do Sul. Revista Brasileira de Zootecnia, Viçosa, MG, v. 35, n. 3, p. 1129-1135, 2006.

PEEL, M. C.; FINLAYSON, B. L.; MCMAHON, T. A. Updated world map of the Koppen-Geiger climate classification. Hydrology and Earth System Sciences, Munich, v. 11, p. 1633-1644, 2007.

PESSOA, R. B.; BLAGITZ, M. G.; BATISTA, C. F.; SANTOS, B. P.; PARRA, A. C.; SOUZA, F. N.; DELLA LIBERA, A. M. M. P. Avaliação da apoptose de leucócitos polimorfonucleares $\mathrm{CH} 138+$ em leite bovino de alta e baixa contagem de células somáticas dados preliminares. Arquivo Brasileiro Medicina Veterinária e Zootecnia, Belo Horizonte, v. 64, n. 3, p. 533-539, 2012.

POLLOTT, G. E. Deconstructing milk yield and composition during lactation using biologically based lactation models. Journal of Dairy Science, Champaign, v. 87 , n. 8 , p. $2375-2387,2004$.

QIAO, F.; TROUT, D. R.; XIAO, C.; CANT, J. P. Kinetics of glucose transport and sequestration in lactating bovine mammary glands measured in vivo with a paired indicator/nutrient dilution technique. Journal of Applied Physiology, San Diego, v. 99, n. 3, p. 799-806, 2005.

RIGOUT, S.; LEMOSQUET, S.; VAN EYS, J. E.; BLUM, J. W.; RULQUIN, H. Duodenal glucose increases glucose fluxes and lactose synthesis in grass silage-fed dairy cows. Journal of Dairy Science, Champaign, v. 85, n. 3, p. 595-606, 2002.

STATISTICAL ANALYSIS SYSTEM INSTITUTE SAS Institute. SAS/STAT. User's guide: statistics, versão 8.1. 4. ed. Cary, 2000. v. 2.

SCHNEEBERGER, E. E.; LYNCH, R. D. Structure, function and regulation of cellular tight junctions. American Journal of Physiology, Illinois, v. 262, n. 6, p. 647-661, 1992.

SCHUKKEN, Y. H.; WILSON, D. J.; WELCOME, F.; GARRISON-TIKOFSKY, L.; GONZALEZ, R. N. Monitoring udder health and milk quality using somatic cell counts. Veterinary Research, London, v. 34, n. 5, p. 579-596, 2003.

SHOOK, G. E.; SCHUTZ, M. M. Selection on somatic cell score to improve resistance to mastitis in the United States. Journal of Dairy Science, Champaign, v. 77, n. 2, p. 648-658, 1994.

SILANIKOVE, N.; SHAPIRO, F.; MERIN, U.; LEITNER, G. Tissue-type plasminogen activator and plasminogen embedded in casein rule its degradation under physiological situations: manipulation with casein hydrolysate. Journal of Dairy Research, London, v. 80, n. 2, p. 227-232, 2013.

SILANIKOVE, N.; SHAPIRO, F.; SHINDER, D. Acute heat stress brings down milk secretion in dairy cows by up-regulating the activity of the milk-borne negative feedback regulatory system. BMC Physiology, London, v. 9, n. 13, 2009.

SMITH, D. L.; SMITH, T.; RUDE, B. J.; WARD, S. $\mathrm{H}$. Comparison of the effects of heat stress on milk and component yields and somatic cell score in Holstein and Jersey cows. Journal of Dairy Science, Champaign, v. 96, n. 5, p. 3028-3033, 2013.

STELWAGEN, K.; DAVIS, S. R.; FARR, V. C.; EICHLER, S. J.; POLITIS, I. Effect of once daily milking and concurrent somatotropin on mammary tight junction permeability and yield of cows. Journal of Dairy Science, Champaign, v. 77, n. 10, p. 2994-3001, 1994.

TEIXEIRA, E. K.; OLIVEIRA, M.; PEDRON, C. D.; ROMÃO, M. Avaliação de um modelo de maturidade de gestão do conhecimento: análise de correspondência múltipla. Análises, Porto Alegre, v. 23, n. 2, p. 129-139, 2012.

ZANELA, M. B.; RIBEIRO, M. E. R.; FISCHER, V.; GOMES, J. F.; STUMPF JUNIOR, W. Ocorrência do leite instável não ácido no noroeste do Rio Grande do Sul. Arquivo Brasileiro de Medicina Veterinária e Zootecnia, Belo Horizonte, v. 61, n. 4, p. 1009-1013, 2009. 